\title{
The Impact of the State of Emergency on the Supply of Services and Passenger Demand for Public Transport
}

\author{
Vladimír Konečný ${ }^{1 *}$ and Mária Brídziková ${ }^{1}$ \\ ${ }^{1}$ University of Žilina, The Department of Road and Urban Transport, Univerzitná 1, 01026 Žilina, \\ Slovakia; Email: vladimir.konecny@fpedas.uniza.sk,maria.bridzikova@fpedas.uniza.sk
}

\section{*Corresponding Author: Vladimír Konečný}

Received: 3 October 2020; Revised: 23 October 2020; Accepted: 2 November 2020; Published: 30 November 2020

\begin{abstract}
The paper deals with the research of the demand and supply of public passenger transport services in the state of emergency caused by the COVID-19 disease. The extraordinary situation has been affecting the behaviour and decision-making of passengers and their demand for public transport not only in the Slovak Republic but globally. The situation has caused a significant decline in passenger transport as well as changes in the structure of passengers who still use the public transport system. Several operators have responded to declining demand by reducing the transport services supply, to reduce operating costs. The declining demand is reflected in a decrease in transport revenues and an increase in the demonstrable loss of operators providing public passenger transport services.
\end{abstract}

Keywords: Public transport, COVID-19, demand, supply, state of emergency

\section{Introduction}

The precondition for satisfying the public passenger transport demand is the existence of its potential, which is represented by the population of a given city, region, or country [1,2]. Public passenger transport is considered an instrument of the country's social policy $[3,4]$. The legislation defines it as transport performed to meet the transport needs of people, especially vulnerable population, i.e. pupils, students, and pensioners.

The demand for transport is also referred to as a secondary demand. This means that a primary demand is met through transport. Secondary demand is influenced by various habits, activities, and also by the demand for goods and services. Demand for public passenger transport is determined by various factors [5,6], such as raising of the standard of living, income of inhabitants [7], geographical location, as well as car ownership [8,9]. 
On the other hand, it is important to point out the supply also has a significant impact on public passenger transport demand. There are various articles, research, and experience focused on the influence of individual factors on public passenger transport demand, including the influence of supply and quality of transport services. Supporting demand through these factors can subsequently stimulate the growth in transportation revenues [10,11]. There are studies [12] which argue that demand for public passenger transport is very sensitive to changes in supply. Papon tested hypotheses on how changes in public passenger transport supply affect its demand. [13] On the other hand, it is necessary to emphasize that it is a complex of factors that determine demand and a simple change in the scope of supply (its increase) may not lead to an increase in demand. The issue needs to be addressed comprehensively [14], including increasing the quality of transport services. However, the impact of the supply on the demand cannot be ignored. Bonnel and Chausse argue that increasing the scope of supply has led to an increase in demand for public passenger transport in Swiss cities [14]. Stopka et al. presented the outcomes of the research focused on passengers' subjective point of view on the Integrated Transport Systems (ITS) comparing with the separate non-integrated traffic lines [15].

In the Slovak Republic, the COVID-19 disease was first confirmed on March 6, 2020. Since then, the number of infected people in Slovakia has increased. On March 12, 2020, strict measures to prevent the spread of COVID-19 were taken in Slovakia, and on March 15, 2020, The Government of the Slovak Republic declared a state of emergency, due to which retail shops, schools, offices, and businesses were closed. During the state of emergency, some companies suspended production, some adjusted the shifts, and some operated without restrictions, but with the newly adopted safety measures.

Operators in public passenger transport also responded to the situation by applying measures to prevent the spread of coronavirus based on the decisions of the Crisis Staff of the Slovak Republic and local self-governments. Operators started to provide limited services under strict epidemiological measures. Passengers were asked get on buses only with covered nose and mouth and to prefer cashless payment on vehicles, as it was already common in other countries around the world, e.g. in China, or in Ghana [16,17].

When commuting to work, for leisure activities, for medical care, or to the authorities, some passengers began to prefer alternative modes of transport, especially individual car transport, due to virus-related concerns $[18,19]$. This change persists in the current period and may intensify with the growing number of positive cases of COVID-19 disease [20].

The main aim of this paper is to point out significant changes in public passenger transport supply and demand during the state of emergency related to the spread of COVID-19. It is also very important to emphasize that operators have reported significantly lower revenues in recent months 
compared to the situation before the coronavirus crisis. This is related to the state of emergency and also to the fact that certain groups of passengers have started to change their habits and use transport services only to a limited extent.

\section{Literature Review}

This chapter presents the research results of authors who also deal with the issues of COVID-19 impact on the functioning of public passenger transport.

Jonas De Vos (2020) pointed out that due to COVID-19, various measures have been taken to reduce travelling and participation in public activities in many countries. On the one hand, social distance has a positive effect on reducing the spread of COVID-19, but on the other hand, the demand for travelling can also be expected to decrease and people will use public transport less often. He also stated that the declining number of passengers during the pandemic also had an impact on public transport funding. Several operators have encountered this issue, so it is appropriate for the government or another public administration authority to help with its cofinancing [18].

Budd et al. (2020) argue that the current situation could be used to make post-crisis transport more sustainable and eco-friendly. The authors point to the changes associated with the COVID-19 crisis and changes in passenger behaviour. Responsible transport can respond to the fact that after the end of the pandemic, transport can change significantly, as it is a suitable opportunity to set up new ways of commuting to work, school, office, leisure activities, etc. [21].

The importance of taking effective, preventive, and control measures in public passenger transport is also highlighted by Shen et al. (2020). They believe that multilateral strategies can increase public transport security. The aim was to present the experience with public transport prevention and control measures in China to support the global response to COVID-19 [22].

Dzisi et al. (2020) made research about wearing face masks in public passenger transport. The research was conducted in Ghana. The data was obtained at the station, where the researchers were interested in how many passengers were on the vehicle (thus whether the required distance between people was kept) and how many of them did not wear a face mask. Based on this data, a correlation analysis was carried out to determine the change in the number of infected people and the change in the mobility of the population. In terms of using face masks on public transport, there was complete compliance (fewer than 3 people without face masks) for about $12.6 \%$ of the time spent on the vehicle. Complete disregard for the policy on face masks (fewer than 3 people wearing a mask on a vehicle) also occurred for about $21.3 \%$ of the time. On average, 4 people per vehicle did not wear face masks. These results indicate existence of a significant gap in implementing the policy on face masks and the need for its much more effective implementation [17]. 
Abu-Rayash and Dincer (2020) analyse the impact of COVID-19 on the transport sector and subsequent implications on the sectoral energy savings and greenhouse gas emissions in some selected cities worldwide. A model for smart transportation is proposed by considering four indicators, including transport efficiency, technology integration, traffic congestion rate, and accessibility ratio. While previous health crises, such as SARS, affected the transportation sector, the COVID-19 pandemic is unprecedented, resulting in particularly serious impacts on this sector. It is expected and reasonable to assume that the public's response to COVID-19 will exceed that of SARS. While the Britons and Canadians are the biggest supporters of keeping the economy and businesses shut until COVID-19 is fully eliminated, the Chinese, Russians, Indians, and Italians find it vital to restart the economy regardless of whether it is still present or not. Results show that the majority of the world is in a state of mental distress and will face post-COVID-19 issues with nervousness and anxiety [20].

\section{Methodology}

The subject of the paper is research of the demand, supply, and revenues from public transport for five groups of public transport passengers in terms of the valid tariff conditions (discounted fares):

- children from $6-15$,

- $\quad$ secondary school and university students,

- citizens over 70 years,

- pensioners,

- disabled persons and persons with reduced mobility.

The total number of transported passengers in public transport is also examined, including the number of persons using discounted fare, full fare, and no fare. The above-mentioned groups of passengers using discounted fare are a part of the total number of passengers using public transport.

Time series of data were provided for a specific public transport system by months for the period from 2015 to 2019. For 2020, data was provided for the months of January to June.

The methods of time series characteristics were used for the research, namely the relative growth (change) of the time series values and the average growth coefficient of the time series.

Coefficient of growth (changes) of the time series (growth rate):

$$
k_{t}=\frac{y_{t}}{y_{\mathrm{t}-1}} \quad(-), \mathrm{t}=2,3, \ldots, \mathrm{n},[-]
$$

where: $y_{t}$ is the current period; $\mathrm{y}_{\mathrm{t}-1}$ is the immediately preceding period.

A modified version of equation (1) is used, expressing the percentage change of the quantity between the two periods:

$$
k_{t}=\left(\frac{y_{t}}{y_{\mathrm{t}-1}} * 100\right)-100,[\%]
$$


The growth coefficient is used in Chapter 3 to evaluate the year-on-year changes in demand, supply, and revenues in public transport due to COVID-19.

Average growth coefficient of the time series (average growth rate):

$$
\bar{k}_{t}=\sqrt[n-1]{\frac{y_{n}}{y_{1}}},[-]
$$

where: $n$ is the number of time series [pcs]; $y_{1}$ is the value of the $1^{\text {st }}$ member of the time series [pcs]; $y_{n}$ is the value of the $\mathrm{n}^{\text {th }}$ member of the time series [pcs].

A modified version of equation (3) is used, expressing the average percentage change of the quantity in the observed period:

$$
\bar{k}_{t}=\left(\left(\sqrt[n-1]{\frac{y_{n}}{y_{1}}}\right) * 100\right)-100,[\%]
$$

\section{Results of the Impact of the State of Emergency on Passenger Demand, the Scope of Supply and Revenue of the Operator}

Changes in passenger behaviour and satisfying the demand for public passenger transport are related to the secondary transport demand. The state of emergency associated with COVID-19 has also affected public passenger transport in the Slovak Republic. Epidemiological measures taken in the field of public transport have been subsequently reflected in the behaviour and demand for public transport.

As an example, we present the results of research in urban public transport operated in the conditions of the Slovak Republic. In terms of size and category of the city according to the classification of the Statistical Office of the Slovak Republic, the examined city has a population of 20,000 to 49,999 inhabitants.

In the conditions of the Slovak Republic, we examined the impact of the state of emergency caused by COVID-19 on these characteristics based on data obtained on the development of demand expressed by the number of transported passengers, on the supply expressed on the number of kilometres travelled by public transport vehicles and on public transport revenues as well.

Due to the sensitivity of the data, we do not provide the transport service operator's name and absolute data on demand, supply, and sales. The results and evaluation of the monitored indicators are presented in a relativized form of year-on-year changes.

In association with the COVID-19 pandemic situation, which began in Slovakia in March 2020, the data on demand, supply, and sales for January - June 2020 in a specific public transport system obtained for research purposes. The impact of the pandemic has unfolded since March 2020. 


\subsection{Research on the Demand for Public Transport and its Changes Caused by the State of Emergency}

Using the available data on the number of passengers transported by public transport system (by individual passenger groups and in total) and the relationship (2), year-on-year percentage changes in passenger demand in January - June 2020 are calculated and presented in Figure 1.
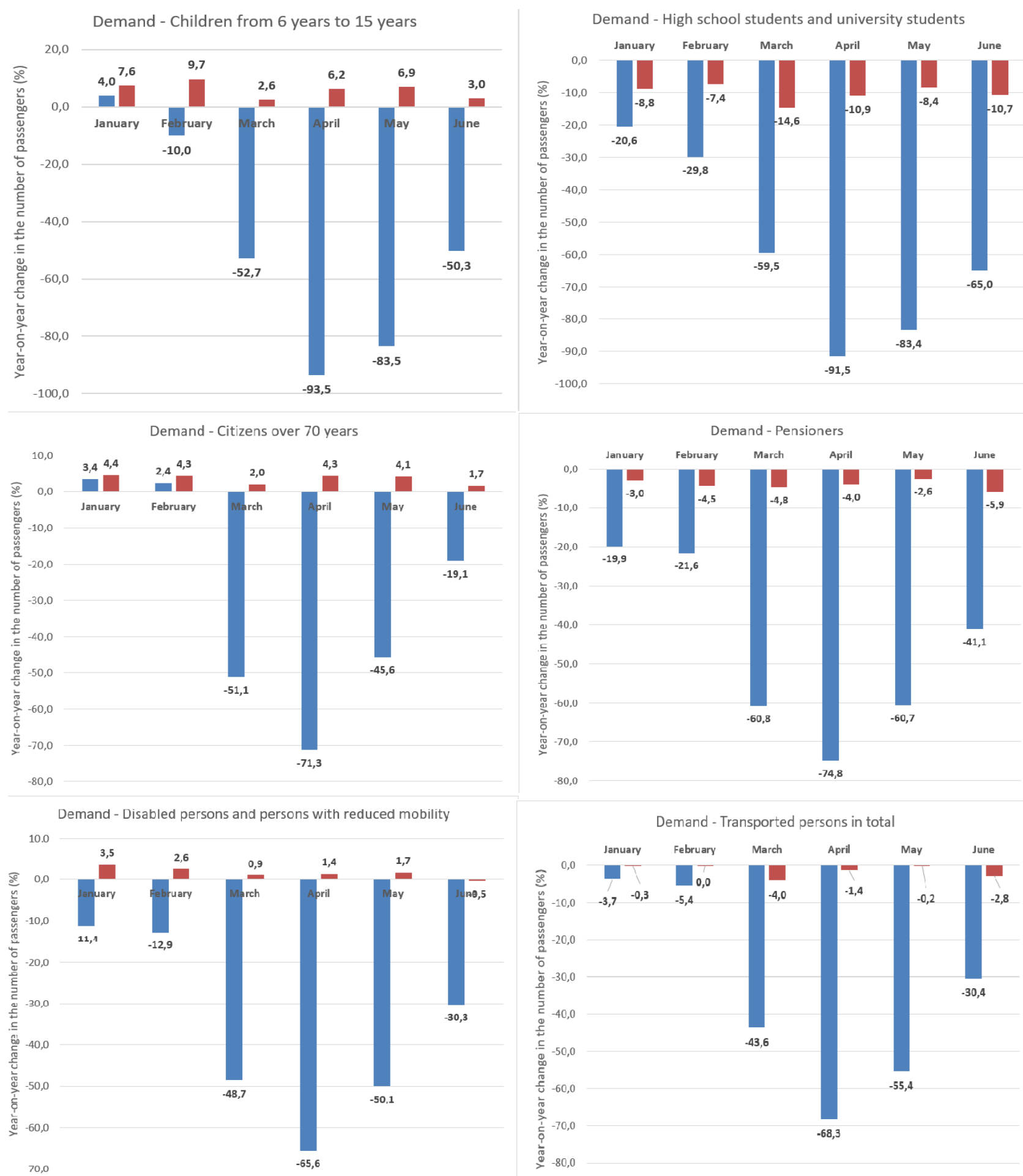

- Year-on-year change 2020 compared to 2019 (\%)

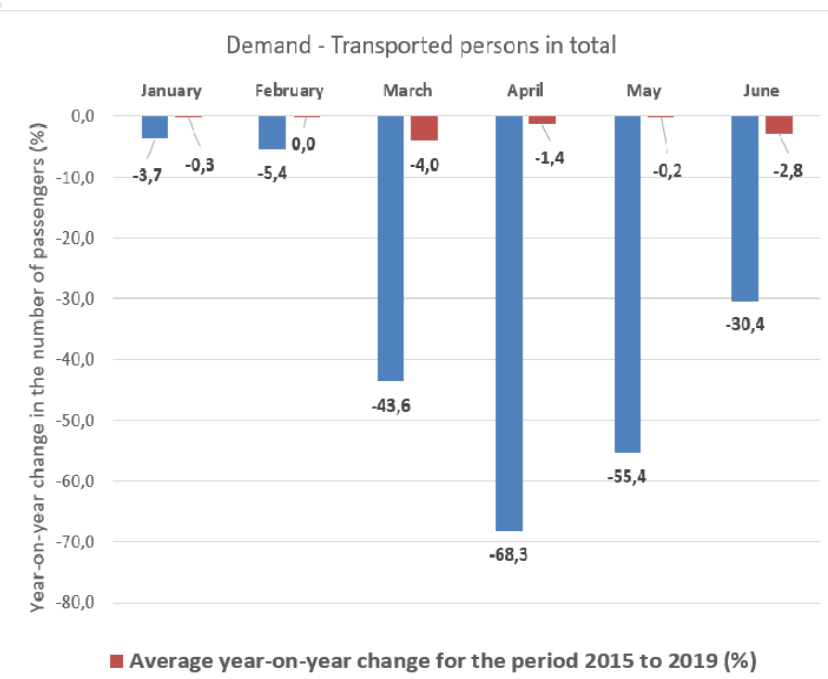

Fig. 1 Comparison of year-on-year changes in demand in \% by type of fare. Source: authors 
For comparison with the change in demand at the time of the state of emergency associated with the COVID-19 pandemic, Fig. 1 also presents groups contains for groups and passengers the values of average year-on-year changes in demand in the period 2015 to 2019 (before the pandemic) for groups and passengers for the evaluated months. The values are calculated based on Equation (4).

The largest decrease in the number of transported passengers was recorded in April 2020, a year-on-year decrease in public transport by 68.3\%, followed by May 2020 (a year-on-year decrease by $55.4 \%$ ), and March (a year-on-year decrease by $43.6 \%$ ). The year-on-year decline in demand slowed slightly in June 2020 compared with the decline in March - May 2020, representing a $30.4 \%$ decrease in total.

In terms of groups of passengers, the decrease was most significant in the case of Children aged 6 to 15 years (a 93.5\% decrease in April 2020), secondary school and university students (a 91.5\% decrease in April 2020), pensioners (decrease by 74.8\% in April 2020), followed by citizens over 70 years of age - the most endangered group in the pandemic situation (April 2020 decrease by $71.3 \%$ ) and disabled persons or persons with reduced mobility (a decrease by $68.3 \%$ in April 2020). A graphical comparison of the overall changes is also shown in Figure 1.

\subsection{Research on the Supply for Public Transport and its Changes Caused by the State of Emergency}

Operators of transport services in the public interest responded to the situation and declining demand by reducing the supply of transport services. During the state of emergency - the first wave of COVID-19 in Slovakia (March to June 2020) - several operators provided "holiday" schedule of transport services, some created new schedules for the situation to ensure the mobility of the population and to minimize losses.

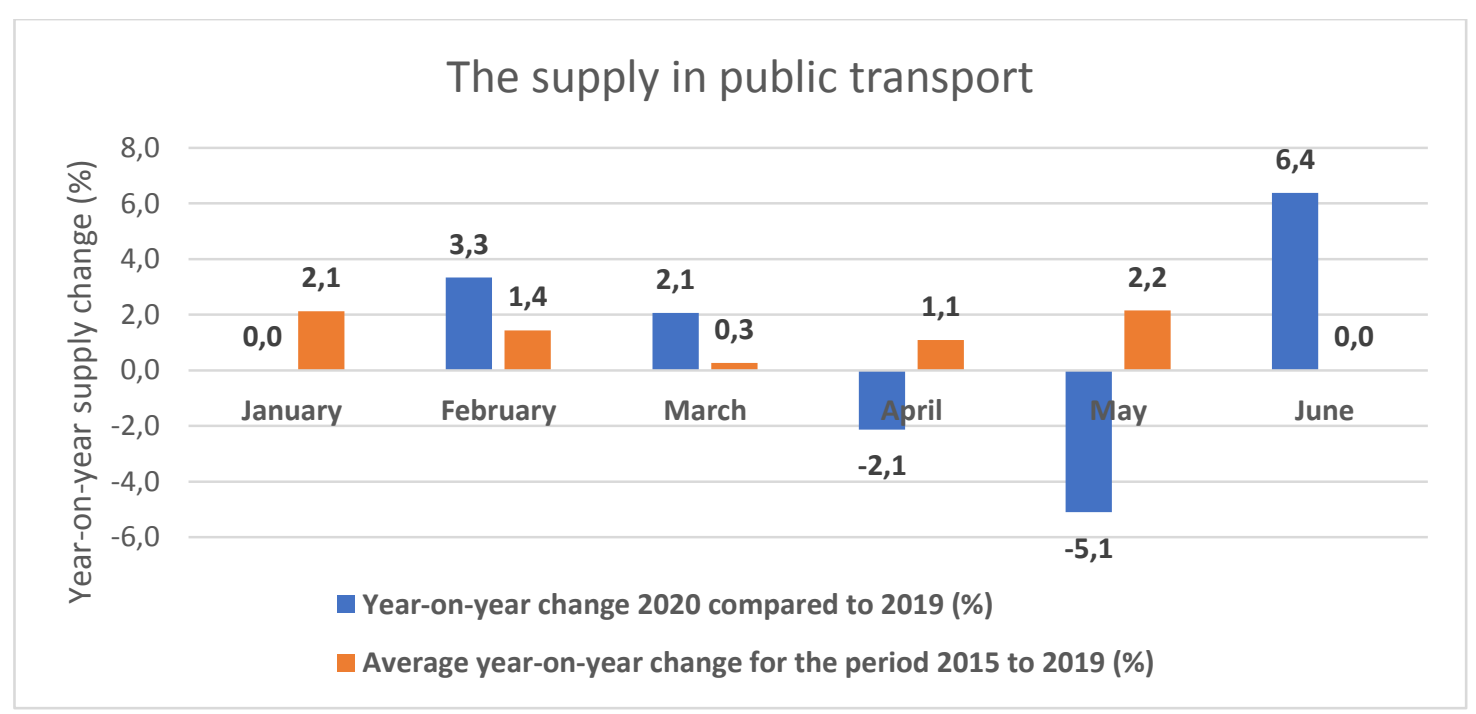

Fig. 2 Comparison of year-on-year changes in the supply in public transport in \%. Source: authors 
In the examined transport company, there was a slight decrease in the offer of services expressed by the number of kilometres travelled on public transport vehicles in April 2020 (-2.1\%) and May 2020 (-5.1\%). In June 2020, with the cancellation of epidemiological measures, the supply increased by $6.4 \%$ compared to the same month of the previous year.

Figure 2 also shows, for comparison, the average year-on-year changes in supply for the period from 2015 to 2019.

\subsection{Research on the Revenues from Public Transport and its Changes Caused by the State of Emergency}

The decline in public transport revenues correlates with the decline in public transport passenger demand. Figure 3 shows the year-on-year percentage changes in public transport revenues by passenger groups and in public transport as a whole from January to June 2020. For comparison with the change in revenues during the state of emergency, Fig. 4 also shows the values of average year-on-year changes in revenues in the period from 2015 to 2019 (before the pandemic) for the evaluated months for groups of passengers. The values of the average year-on-year changes in sales are calculated according to the relation (4).

The largest decrease in revenues occurred in April 2020, year-on-year change for public transport by $65.1 \%$, followed by May 2020 (year-on-year decrease by 54.7\%) and March (year-onyear decrease by $42.8 \%$ ). The year-on-year decline in revenues slowed down slightly in June 2020 compared to the decline in March to May 2020, down by $31.5 \%$.

In terms of the groups of passengers, the decrease in revenues was most significant in the case of Children aged 6 to 15 (a decrease of 93.2\% in April 2020), secondary school and university students (a 91.4\% decrease in April 2020), pensioners (a decreased by $74.8 \%$ in April 2020), followed by citizens over 70 years of age - the most endangered group of people (a decrease by $71.3 \%$ in April 2020), and disabled persons and persons with reduced mobility (a decrease by 65.6 $\%$ in April 2020). 


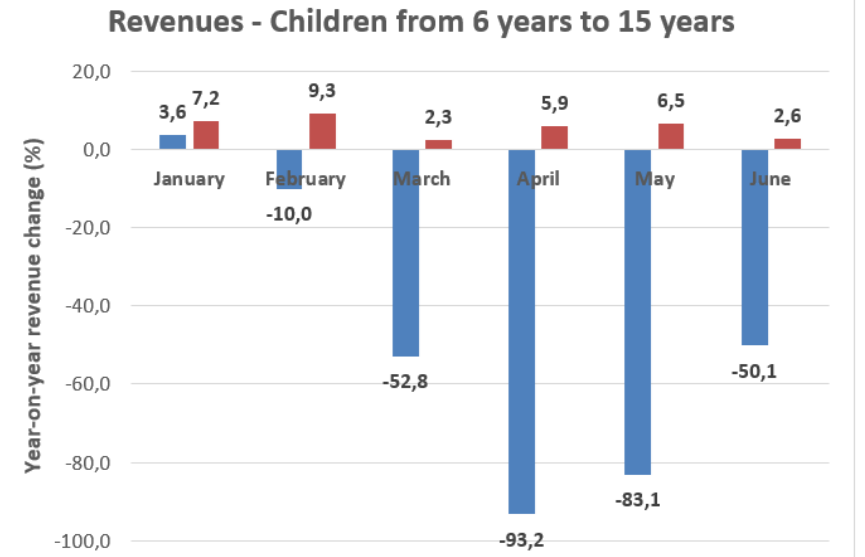

Revenues - High school students and university students

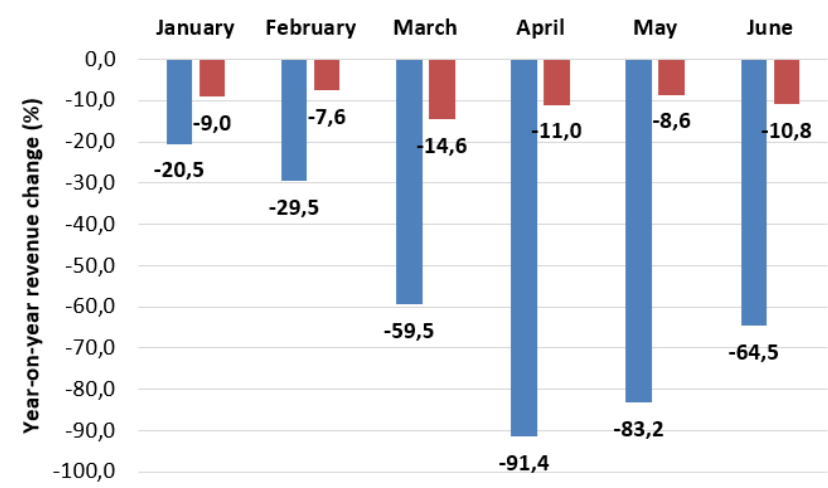

Revenues - Citizens over 70 years

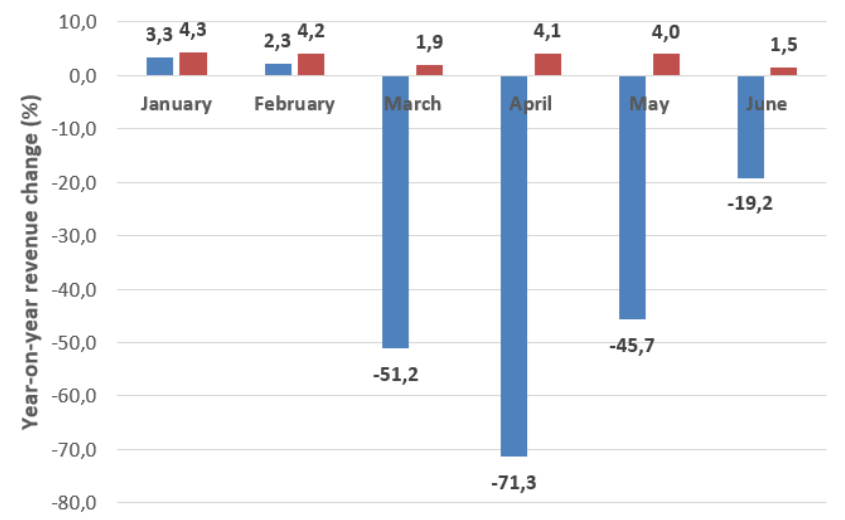

E Year-on-year change 2020 compared to 2019 (\%)

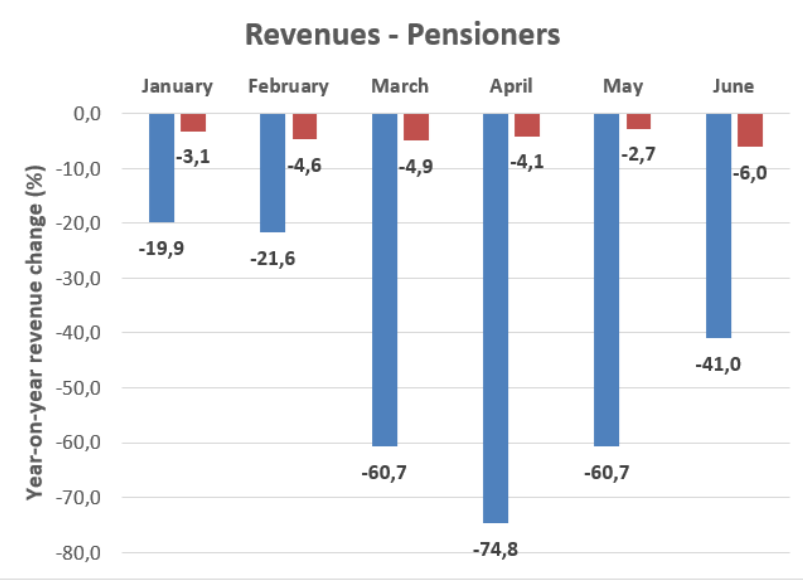

Revenues - Disabled persons and persons with reduced mobility

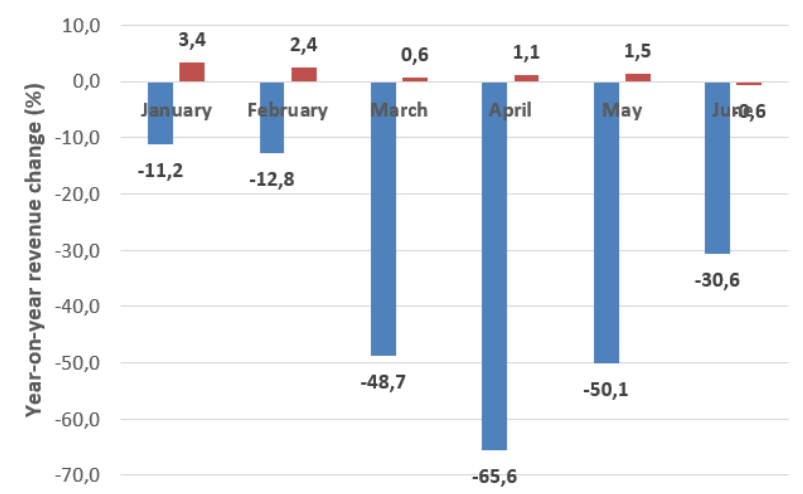

Revenues - Transported persons in total

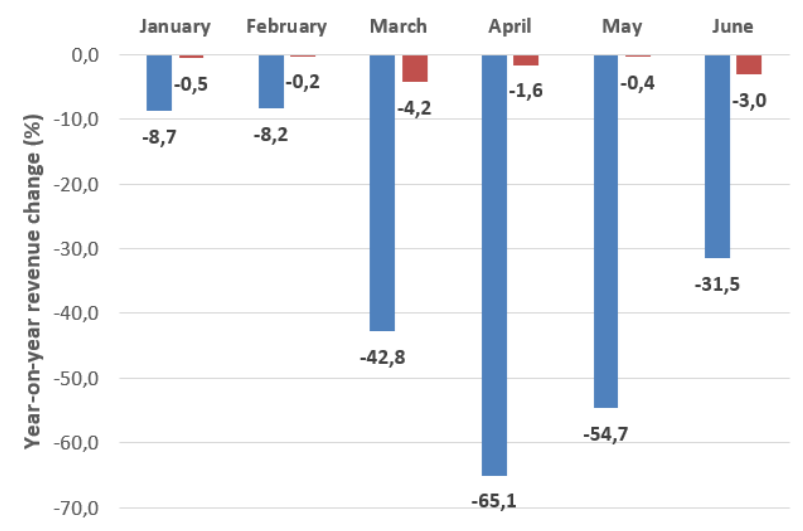

- Average year-on-year change for the period 2015 to 2019 (\%)

Fig. 3 Comparison of year-on-year changes in revenues in \% by type of fare. Source: authors

\section{Conclusion}

The extraordinary situation caused by the COVID-19 disease affected the demand for public passenger transport in the Slovak Republic, which confirmed our study on a specific public transport operator in a selected city. Similar results can be assumed in other public passenger transport systems.

The spread of COVID-19 has led to measures in many countries to restrict travelling and participation in activities. Policy makers and governments should therefore seek to encourage 
travelling, while public transport operators should focus on creating ways to use public transport safely $[18,21]$.

The development of demand in recent years is characterized by its constant decline not only in the Slovak Republic; the situation caused by COVID-19 has increased and accelerated this decline. The state of emergency has an impact on changing the transport habits of various groups of passengers. There is a risk that some passengers will use alternative ways of transport and will not return to public passenger transport systems after the end of the pandemic.

Such research on the change of transport habits is currently being methodologically prepared by the authors of the paper in the form of direct questioning of passengers to determine their habits and the impact of the COVID-19 pandemic on the change of their transport habits.

COVID-19 also has a significant impact on future demand estimates and forecasts, as the situation persists even though the state of emergency is cancelled in the time of writing this paper. The reduction in passenger demand and transport revenues is more pronounced compared to the reduction in the supply of transport services. Our research showed that in April 2020, the demand for public transport decreased by $68.3 \%$. Revenues from public transport decreased by $65.1 \%$ in the given month, the scope of the supply of public transport services decreased by $5.1 \%$. The reduction in supply was not so drastic. A more significant reduction in supply would subsequently determine demand and related revenues, which would lead to a further decline.

One of the ways to keep passengers in the public passenger transport system is to increase the quality of transport services and ensure that the quality requirements of passengers are met. With these measures, it is possible to partially eliminate the imminent further outflow of passengers from the public transport system caused by changes in the transport habits of individual groups of passengers.

The issue of financing services in the public interest in similar situations also needs to be addressed. One of the recommendations for the future could be to create a plan that would comprehensively address the consequences of the state of emergency from the operators' point of view, which would define the methods of bearing and covering up the losses of the operators due to loss of revenues caused by the implementation of the limited supply of transport.

\section{Acknowledgments}

This paper has been developed under support of project: MŠVVŠ SR VEGA No. 1/0566/18 KONEČNÝ, V.: Research on the impact of supply and quality of transport services on the competitiveness and sustainability of demand for public transport. 


\section{References}

[1] Veterník, M. \& Gogola, M. (2017). Examining of correlation between demographic development of population and their travel behaviour. Procedia Engineering 192, 929 - 934. DOI: 10.1016/j.proeng.2017.06.160.

[2] Demographic trends: How will an aging population affect transport planning and urban regeneration? Retrieved April 2020, from https://www.mayerbrown.co.uk/keep-up-todate/blog/posts/demographic-trends-how-will-an-aging-population-affect-transport-planningand-urban-regeneration/

[3] Holmgren, J. (2014). A strategy for increased public transport usage - The effects of implementing a welfare maximizing policy. Research in transportation Economics 48, 221226. DOI: 10.1016/j.retrec.2014.09.046.

[4] Dydkowski, G. \& Gnap, J. (2019). Premises and limitations of free public transport implementation. Communications - Scientific Letters of the University of Žilina 21(4), 13-18. DOI: 10.26552/com.C.2019.4.13-18.

[5] Kral, P., Janoskova, K. \& Klieštik, T. (2018). Key determinants of the public transport user's satisfaction. Administratie si Management Public 31, 36-51. DOI: 10.24818/amp/2018.31-03.

[6] Metz, David. (2012). Demographic determinants of daily travel demand. Transport Policy 21, 20-25. DOI: 10.1016/j.tranpol.2012.01.007.

[7] Holmgren, J. (2013). An analysis of the determinants of local public transport demand focusing the effects of income changes. European Transport Research Review 5(2), 101-107. DOI: $10.1007 / \mathrm{s} 12544-013-0094-0$.

[8] Gašparík, J., Stopka, O. \& Pečený, L. (2015). Quality evaluation in regional passenger rail transport. Naše More 62, 114-118. DOI: 10.17818/NM/2015/SI5.

[9] Paulley, N., Blacombe, R., Mackett, R., Titheridge, H., Preston, J., Wardman, M., Shires, J. \& White, P. (2006). The demand for public transport: The effects of fares, quality of service, income and car ownership. Transport Policy 13(4), 295-306. DOI: 10.1016/j.tranpol.2005.12.004

[10] Poliak, M., Gnap, J. \& Konečný, V. (2018). Ekonomika dopravného podniku. 1. Vydanie. Žilina. EDIS. s.197. ISBN 978-80-554-1444-7.

[11] Poliak, M. (2013). Relationship of reasonable profit and risk in public passenger transport in the Slovak republic (in Slovakia). Journal of Economics 61(2), 206-220.

[12] Bresson, G., Dargay, J., Madre, J. \& Pirotte, A. (2004). Economic and structural determinants of the demand for public transport. An analysis on a panel of French urban areas using shrinkage estimators. Transport Research Part A-Policy and Practice 38(4), 269-285. DOI: 10.1016/j.tra.2003.11.002.

[13] Papon, F. (2002). Forecasting travel in the Paris region: Benefits and limits of an econometric approach. Recherche - Transport - Securite 77, 243-258. DOI: 10.1016/s07618980(02)90002-6.

[14] Bonnel, P. \& Chausse, A. (2000). Urban travel: competition and pricing. Transport Reviews 20(4), 385-401. DOI: 10.1080/01441640050150658.

[15] Stopka, O., Bartuška, L. \& Kampf, R. (2015). Passengers' evaluation of the integrated transport systems. Naše More 62, 153-157. DOI: 10.17818/NM/2015/SI12.

[16] Shen, J., Duan, H., Zhang, B., et.al. (2020). Prevention and control of COVID-19 in public transport: Experience from China. Environmental Pollution 266, DOI: 10.1016/j.envpol.2020.115291. 
[17] Dzisi, E. \& Dei, O. (2020). Adherence to social distancing and wearing of masks within public transportation during the COVID 19 pandemic. Transportation Research Interdisciplinary Perspectives 7. DOI: 10.1016/j.trip.2020.100191.

[18] De Vos, J. (2020). The effect of COVID - 19 and subsequent social distancing on travel behavior. Transportation Research Interdisciplinary Perspectives 5. DOI: 10.1016/j.trip.2020.100121.

[19] Parady, G., Taniguchi, A. \& Takami, K. (2020). Travel behaviour changes during the COVID-19 pandemic in Japan: analyzing the effects of risk perception and social influence on going -out self-restriction. In Transportation research Interdisciplinary Perspectives 7. DOI: https://doi.org/10.1016/j.trip.2020.100181.

[20] Abu-Rayash, A. \& Dincer, I. (2020). Analysis of mobility trends during the COVID-19 coronavirus pandemic: exploring the impacts on global aviation and travel in selected cities. Energy Research \& Social Science 68. DOI: 10.1016/j.erss.2020.101693.

[21] Budd, L., Ison, C.S. \& Stephen G. (2020). Responsible transport: A post - COVID agenda for transport policy and practice. Transportation Research Interdisciplinary Perspectives 6. DOI: 10.1016/j.trip.2020.100151.

[22] Shen, J., Duan, H., et al. (2020). Prevention and control of COVID-19 in public transportation: Experience from China. Environmental Pollution 266, DOI: 10.1016/j.envpol.2020.115291. 